\title{
STATICS AND KINEMATICS IN CYCLIC BEHAVIOUR OF SEMI-RIGID STEEL STRUCTURES
}

\author{
Moldovan Corina - Ana \\ Technical College “A. Saligny”, Cluj-Napoca, Romania, Bulevardul 21 Decembrie 1989, nr 128-131, jud. Cluj, \\ e-mail: corina_mold2003@yahoo.com
}

Received: 27.07.2016 / Accepted: 01.08.2016 / Revised: 15.10.2016 / Available online: 15.12.2016

\section{DOI: 10.1515/jaes-2016-0014}

KEY WORDS: lateral displacement, drift, base shear force

\begin{abstract}
:
The contribution presents a set of seismic analyses of multi - storey steel structures with semi-rigid beam column connections acted upon by seismic actions. Semi-rigidity of the structures beam to column connections is conferred by two types of beam to column connections: top and seat and web angle (TSW) and end-plate (EP) joints. Computed numerical results are associated to two classes (static and kinematic) of seismic behaviour parameters expressing the two contradictory effects of semi-rigidity. On one hand, the lateral flexibility induces larger lateral displacements while, on the other hand, it attracts smaller base shear seismic forces. Also, the constitutive relation $M-\theta_{r}$ induced into semi- rigid beam column connections by seismic actions is presented. The results are presented in their numerical form and in a comparative graphical manner allowing for relevant comments and conclusions.
\end{abstract}

\section{INTRODUCTION}

Seismic behaviour of semi-rigid multi- storey steel structures has been the objective of a large area of research extended over a relative short period of time (Bjorhovde et al., 1990), (AlSalloum et al., 1995), (Abdalla et al., 1995). A great deal of work is dedicated to analytical $M-\theta_{r}$ models of semi- rigid beam column connections (Dubina et al., 1996), (Moldovan, 1997), (Goto et al., 1998), (Degertekin et al., 2004). In time, the most satisfactory results of these models have been grouped into a few analytical models (Chan et al., 2005), (Moldovan, 2005), (Del Savio et al., 2009). Nevertheless, the models cover monotonic increase in the mechanical state of the connections only. Cyclic behaviour of, both at structural level and beam column joint level is, still, of large theoretical and laboratory research (Lima et al., 2005), (Kartal et al., 2010), together with modern numerical approach (Chan et al., 2000)). Increased interest in semi-rigidity requires periodic review of the literature that aims at emphasizing common aspects novelties and trends in the area (Trahair, 2012), (Fang et al., 2013). Regarding seismic behaviour of semi-rigid multi - storey structures, a popular image is associated to a decreased in lateral stiffness induced by semi- rigidity of beam column connections and, consequently - larger floor level lateral displacements. If kinematic state is mainly regarded, larger floor level lateral displacements do not constitute the aim of structural design. Kinematic state has to be reviewed together is dual part - static state. Inside static state, the seismic base shear force helps to make up a more general and relevant mechanical state. Indeed, (Moldovan, 2016) a decreased lateral stiffnessvia semi - rigidity in this case- leads to smaller base shear seismic forces and, therefore, smaller static equivalent floor level seismic forces. A simple understanding of apparently, static kinematic contradiction in the seismic behaviour of multi - storey steel structures may be achieved if semi- rigidity is associated to free vibration state of these structures. Vibration periods - mainly their fundamental component- may, now, be directly related to seismic behaviour semi-rigid multi - storey structures. Semi - rigidity means more flexible structures therefore, higher fundamental vibration periods and, consequently, smaller base shear seismic forces. Here lies the objective of presented contribution: the study of mechanical state (in its both, static and kinematic components) induced by seismic actions to semi-rigidly connected steel structures.

The objective is achieved by means of numerical seismic analyzes carried out on semi-rigid two planar steel frames (of four and six stories, respectively) acted upon by two seismic actions (Emeryville 1989, Vrancea 1977 ). Two types of semirigid beam-column connections are considered: top and seat and web angle (TSW) and end- plate (EP). Both types of semirigid connections are, then, considered in several degrees of semi-rigidity. Computed parameters are lateral floor displacements (both, absolute and relative values) and seismic base shear force. Also, resulted constitutive relation $M-\theta_{r}$ in their graphical forms- are presented.

\section{ANALIZED STRUCTURES. SEMI-RIGID CONNECTIONS. SEISMIC ACTIONS}

Two planar steel frames have been designed, according to Romanian design codes (P100-1, 2013) (Eurocode, 2005). Each structure is made of three spans and four (Figure 1), respectively, six stories (Figure 2). 


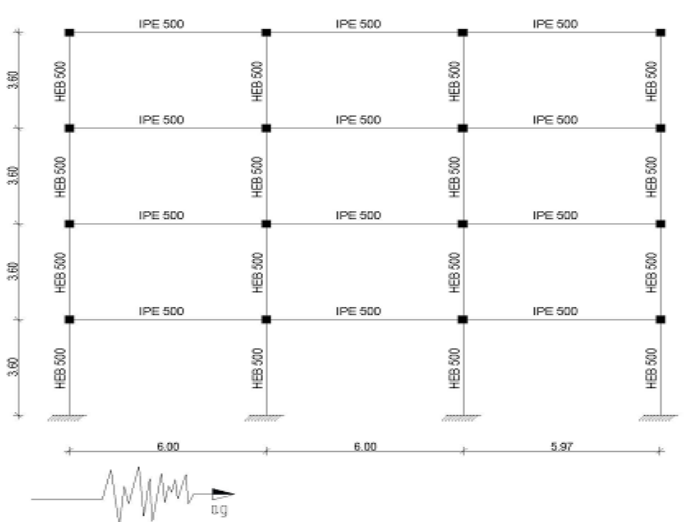

Figure 1. Four storey frame

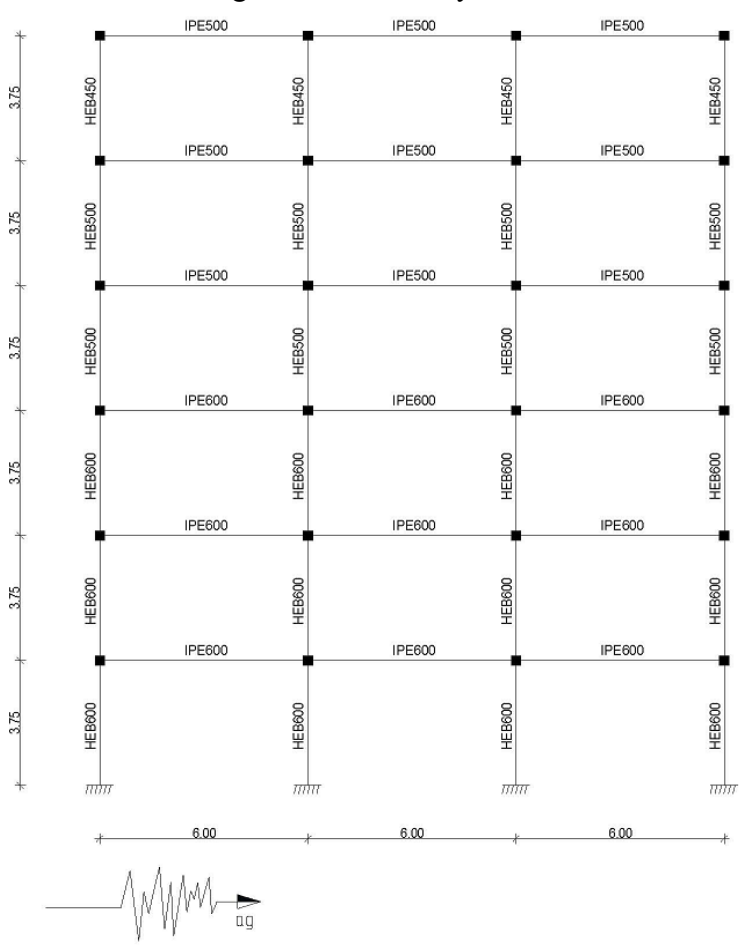

Figure 2. Six storey frame

First type (TSW) semi-rigid connection is (Figure 3) is considered in six degrees of semi-rigidity (Table 1 ).

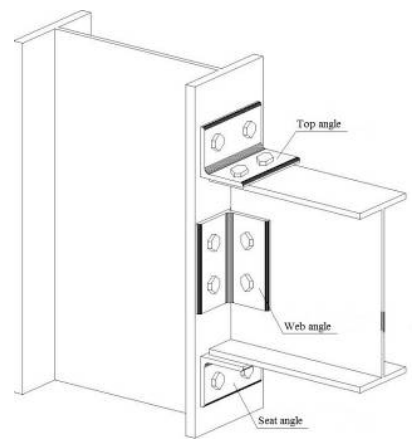

Figure 3. TSW semi-rigid connection

\begin{tabular}{|c|c|c|c|}
\hline \multirow[b]{2}{*}{$\begin{array}{c}\text { Geometrical and } \\
\text { mechanical } \\
\text { characteristics }\end{array}$} & \multicolumn{3}{|c|}{ Type of connection (TSW) } \\
\hline & $\begin{array}{r}\text { TSW } 1 \\
\mathrm{R}_{\mathrm{c}}= \\
5 \mathrm{xR}_{\mathrm{g}} \\
\end{array}$ & $\begin{array}{c}\text { TSW 2 } \\
\mathrm{R}_{\mathrm{c}}= \\
10 \mathrm{xR}_{\mathrm{g}}\end{array}$ & $\begin{array}{c}\text { TSW } 3 \\
\mathrm{R}_{\mathrm{c}}= \\
15 \mathrm{xR}_{\mathrm{g}} \\
\end{array}$ \\
\hline $\mathbf{t}_{\text {Bup }} ; t_{\text {inf }}(\mathrm{mm})$ & 11 & 12 & 13 \\
\hline $\mathrm{t}_{\mathrm{in}}(\mathrm{mm})$ & 10 & 12 & 13 \\
\hline$l_{\text {sup }} ; l_{\text {inf }}(\mathrm{mm})$ & 180 & 200 & 220 \\
\hline$l_{\text {in }}(\mathrm{mm})$ & 200 & 320 & 400 \\
\hline $\mathbf{R}_{\mathbf{i}}(\mathrm{kNm} / \mathrm{rad})$ & $0.88 \times 10^{5}$ & $1.69 \times 10^{5}$ & $2.58 \times 10^{5}$ \\
\hline $\mathrm{M}_{\mathrm{u}}(\mathrm{kNm})$ & 237 & 383 & 509 \\
\hline
\end{tabular}

\begin{tabular}{|c|c|c|c|}
\hline $\begin{array}{c}\text { Geometrical and } \\
\text { mechanical } \\
\text { characteristics }\end{array}$ & \multicolumn{3}{|c|}{ Type of connection (TSW) } \\
\cline { 2 - 4 } & $\begin{array}{c}\mathrm{TSW} 4 \\
\mathrm{R}_{\mathrm{c}}=\end{array}$ & $\begin{array}{c}\mathrm{TSW} 5 \\
\mathrm{R}_{\mathrm{c}}= \\
20 \times \mathrm{R}_{\mathrm{g}}\end{array}$ & $\begin{array}{c}\mathrm{TSW} 6 \\
\mathrm{R}_{\mathrm{c}}=3 \\
0 \times \mathrm{R}_{\mathrm{g}}\end{array}$ \\
\hline $\mathrm{t}_{\text {gup }} ; \mathrm{t}_{\text {inf }}(\mathrm{mm})$ & 14 & 15 & 16 \\
\hline $\mathrm{t}_{\mathrm{in}}(\mathrm{mm})$ & 14 & 15 & 16 \\
\hline $\mathrm{l}_{\text {sup }} ; \mathrm{l}_{\text {inf }}(\mathrm{mm})$ & 230 & 230 & 220 \\
\hline $\mathrm{l}_{\text {in }}(\mathrm{mm})$ & 400 & 400 & 420 \\
\hline $\mathbb{R}_{\mathrm{i}}(\mathrm{kNm} / \mathrm{rad})$ & $3.40 \times 10^{5}$ & $4.29 \times 10^{5}$ & $5.34 \times 10^{5}$ \\
\hline $\mathrm{M}_{\mathrm{u}}(\mathrm{kNm})$ & 586 & 655 & 729 \\
\hline
\end{tabular}

Table 1. Geometrical and mechanical characteristics of semirigid top seat and web angle (TSW) semi-rigid connections for IPE500 beam case

Parameters of connections:

$-t_{\text {sup }}, 1_{\text {sup }}$ - thickness and length of top angle wing

- $t_{\text {inf }}, l_{\text {inf }}-$ thickness and length of seat angle wing

$-t_{\text {in }}, 1_{\text {in }}$ - thickness and length of web angle wing

- $t_{p c}$ - thickness of end plate

- $\mathrm{B}_{\mathrm{pc}}$ - width of end plate

- $\mathrm{R}_{\mathrm{i}}$ - initial stiffness

- $\mathrm{M}_{\mathrm{u}}$ - ultimate bending moment

- $R_{g}$ - beam stiffness

The EP type semi-rigid connection (Figure 4) is considered in two degrees of semi-rigidity (Table $2 \mathrm{a}$ and Table 2b).

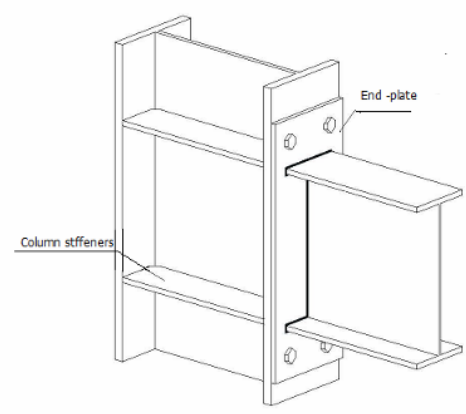

Figure 4. EP semi-rigid connection 


\begin{tabular}{|c|c|c|c|}
\hline \multirow{2}{*}{$\begin{array}{c}\text { Geometrical and } \\
\text { mechanical } \\
\text { characteristics }\end{array}$} & \multicolumn{3}{|c|}{ Type of connection(TSW) } \\
\hline & $\begin{array}{c}\text { TSW 2 } \\
\mathrm{R}_{\mathrm{c}}=10 \times \mathrm{R}_{\mathrm{g}}\end{array}$ & $\begin{array}{c}\text { TSW } 4 \\
\mathrm{R}_{\mathrm{c}}=20 \times R_{\mathrm{g}}\end{array}$ & $\begin{array}{c}\text { TSW 5 } \\
\mathrm{R}_{\mathrm{c}}=25 \times \mathrm{R}_{\mathrm{g}}\end{array}$ \\
\hline $\mathrm{t}_{\text {sup }} ; \mathrm{t}_{\text {inf }}(\mathrm{mm})$ & 12 & 14 & 15 \\
\hline$t_{\mathrm{in}}(\mathrm{mm})$ & 12 & 14 & 15 \\
\hline $\mathrm{l}_{\text {sug }} ; \mathrm{l}_{\text {inf }}(\mathrm{mm})$ & 200 & 230 & 230 \\
\hline$l_{\text {in }}(\mathrm{mm})$ & 320 & 400 & 400 \\
\hline $\mathbb{R}_{\mathrm{i}}(\mathrm{kNm} / \mathrm{rad})$ & $1.69 \times 10^{5}$ & $3.40 \times 10^{5}$ & $4.29 \times 10^{5}$ \\
\hline $\mathrm{M}_{\mathrm{d}}(\mathrm{kNm})$ & 319 & 492 & 530 \\
\hline
\end{tabular}

\begin{tabular}{|c|c|c|}
\hline & $\begin{array}{c}\text { Acceleration, } \mathrm{a}_{\mathrm{g}} \\
\left(\mathrm{m} / \mathrm{s}^{2}\right)\end{array}$ & $\begin{array}{c}\mathrm{T}, \text { predominant } \\
\text { period }(\mathrm{s})\end{array}$ \\
\hline Emeryville 1989 & 1,962 & 1,18 \\
\hline Vrancea 1977 & 1,95 & 1,16 \\
\hline
\end{tabular}

Table 3. Earthquaques

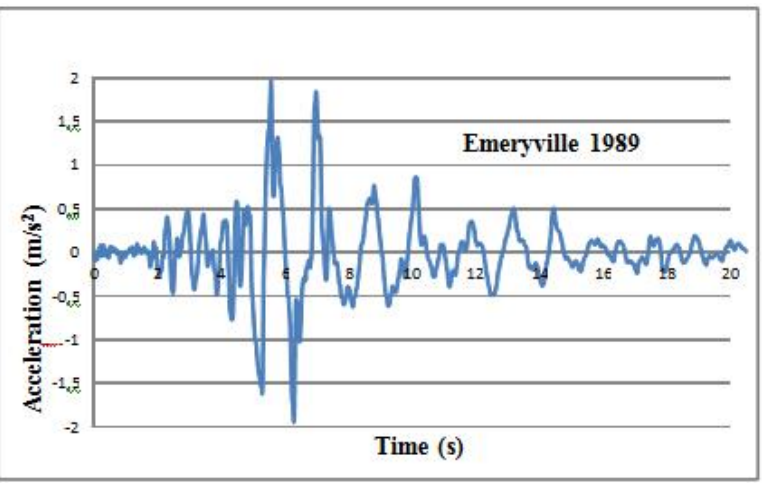

Figure 5. Emeryville 1989 - ground acceleration

\begin{tabular}{|c|c|c|c|}
\hline \multirow{2}{*}{$\begin{array}{c}\text { Geometrical and } \\
\text { mechanical } \\
\text { characteristics }\end{array}$} & \multicolumn{3}{|c|}{ Type of connection(EP) } \\
\cline { 2 - 4 } & EP 1 & EP 2 & EP 3 \\
\hline $\mathrm{t}_{\mathrm{pc}}(\mathrm{mm})$ & 21 & 25 & 26 \\
\hline $\mathrm{B}_{\mathrm{pc}}(\mathrm{mm})$ & 230 & 260 & 250 \\
\hline $\mathrm{R}_{\mathrm{i}}(\mathrm{kNm} / \mathrm{rad})$ & $3.46 \times 10^{5}$ & $5.06 \times 10^{5}$ & $5.31 \times 10^{5}$ \\
\hline $\mathrm{M}_{0}(\mathrm{kNm})$ & 317 & 497 & 530 \\
\hline
\end{tabular}

Table 2a. Geometrical and mechanical characteristics of semirigid top seat and web angle (TSW) and end-plate (EP) semirigid connections for IPE500 beam case

\begin{tabular}{|c|c|c|c|}
\hline $\begin{array}{c}\text { Geometrical and } \\
\text { mechanical } \\
\text { characteristics }\end{array}$ & \multicolumn{3}{|c|}{ Type of connection (TSW) } \\
\cline { 2 - 4 } & $\begin{array}{c}\text { TSW 2 } \\
\mathrm{R}_{\mathrm{c}}=10 \times \mathrm{R}_{\mathrm{g}}\end{array}$ & $\begin{array}{c}\mathrm{TSW} 4 \\
\mathrm{R}_{\mathrm{c}}=20 \times \mathrm{x}_{\mathrm{g}}\end{array}$ & $\begin{array}{c}\mathrm{TSW} 5 \\
\mathrm{R}_{\mathrm{c}}=25 \times \mathrm{R}_{\mathrm{g}}\end{array}$ \\
\hline $\mathrm{t}_{\text {sup }} ; \mathrm{t}_{\text {inf }}(\mathrm{mm})$ & 13 & 15 & 16 \\
\hline $\mathrm{t}_{\mathrm{n}}(\mathrm{mm})$ & 12 & 15 & 16 \\
\hline $\mathrm{l}_{\text {sup }} ; \mathrm{l}_{\text {inf }}(\mathrm{mm})$ & 260 & 270 & 270 \\
\hline $\mathrm{l}_{\text {in }}(\mathrm{mm})$ & 350 & 430 & 450 \\
\hline $\mathbb{R}_{\mathrm{i}}(\mathrm{kNm} / \mathrm{rad})$ & $3.20 \times 10^{5}$ & $6.38 \times 10^{5}$ & $8.10 \times 10^{5}$ \\
\hline $\mathrm{M}_{0}(\mathrm{kNm})$ & 532 & 733 & 810 \\
\hline
\end{tabular}

\begin{tabular}{|c|c|c|c|}
\hline \multirow{2}{*}{$\begin{array}{c}\text { Geometrical and } \\
\text { mechanical } \\
\text { characteristics }\end{array}$} & \multicolumn{3}{|c|}{ Type of connection (EP) } \\
\cline { 2 - 4 } & EP 1 & EP 2 & EP 3 \\
\hline $\mathrm{t}_{\mathrm{pc}}(\mathrm{mm})$ & 23 & 26 & 27 \\
\hline $\mathrm{B}_{\mathrm{pc}}(\mathrm{mm})$ & 270 & 290 & 295 \\
\hline $\mathbb{R}_{\mathrm{i}}(\mathrm{kNm} / \mathrm{rad})$ & $7.18 \times 10^{5}$ & $9.20 \times 10^{5}$ & $9.83 \times 10^{5}$ \\
\hline $\mathrm{M}_{0}(\mathrm{kNm})$ & 535 & 735 & 806 \\
\hline
\end{tabular}

Table 2b. Geometrical and mechanical characteristics of semirigid top seat and web angle (TSW) and end-plate (EP) semirigid connections for IPE600 beam case

The two earthquakes, Vrancea 1977 (Figure 5) and Emeryville 1989 (Figure 6) are given together with their ground induced acceleration $\mathrm{a}_{\mathrm{g}}$ and predominant periods $\mathrm{T}$ (Table 3 ). 


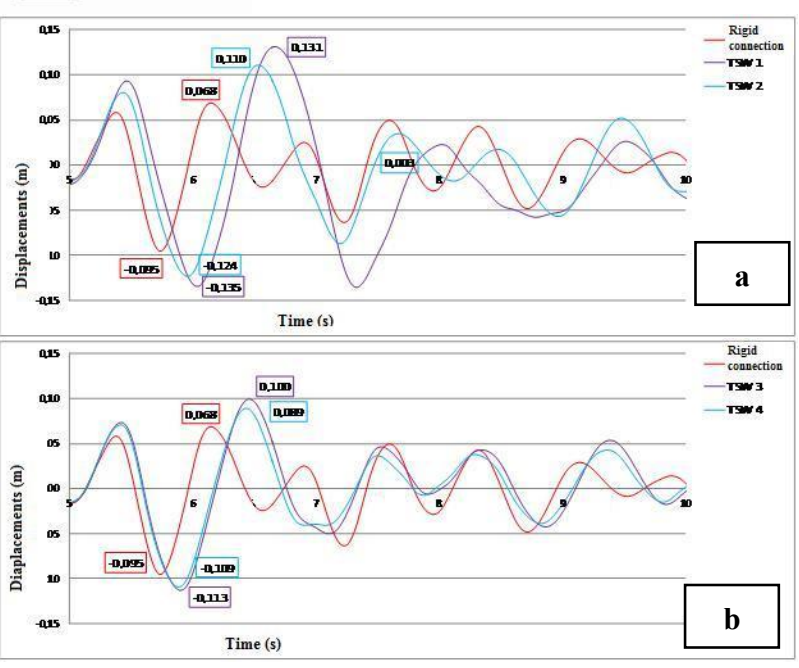

3.1.2. The case of six storey structure

Emeryville 1989:
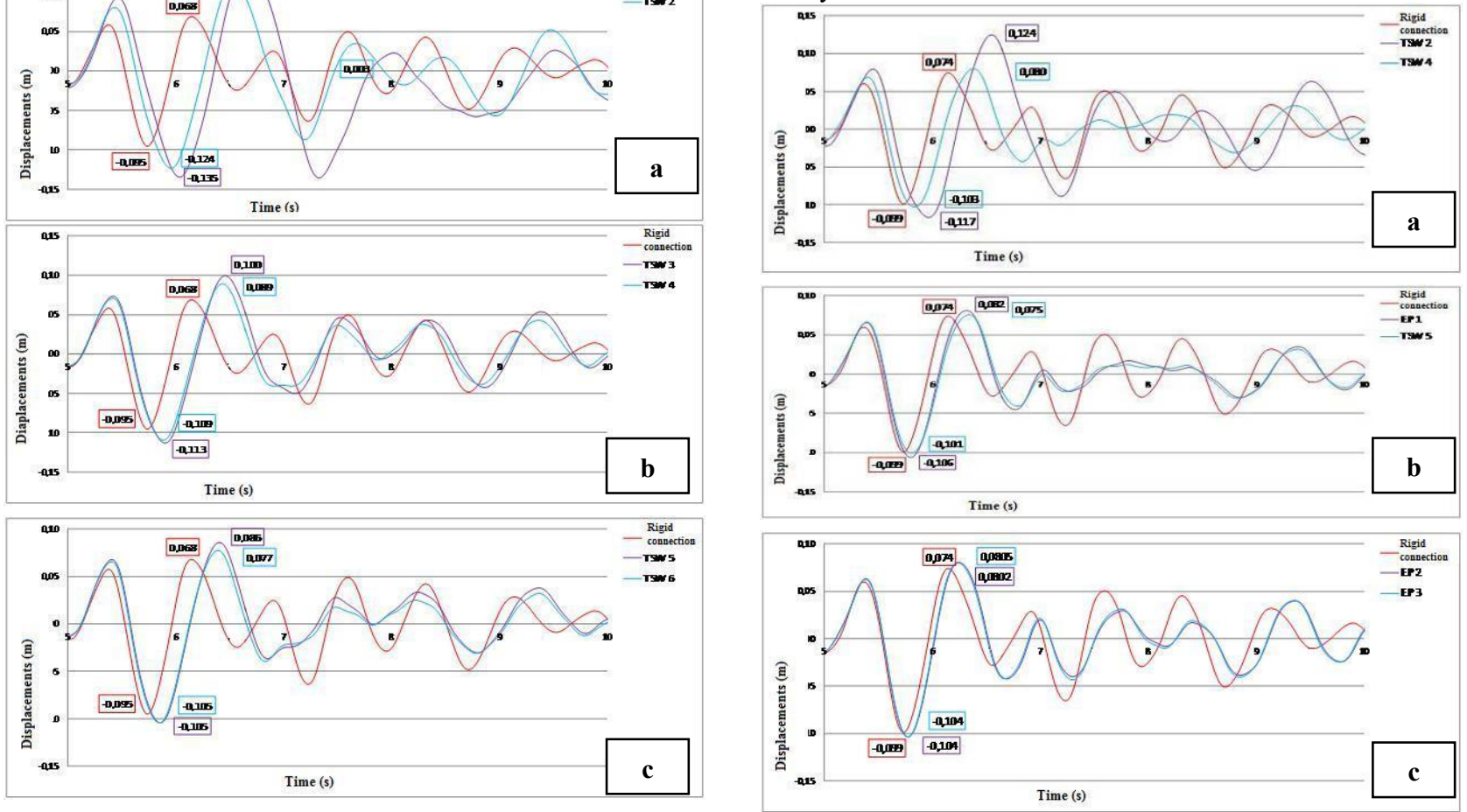

Figure 7. Top lateral displacements: a - Rigid connection, TSW 1, TSW 2; b - Rigid connection, TSW 3, TSW 4; c - Rigid connection, TSW 5, TSW 6

Figure 9. Top lateral displacements: a - Rigid connection, TSW 2, TSW 4; b - Rigid connection, TSW 1, TSW 5; c - Rigid connection, EP 2, EP 3
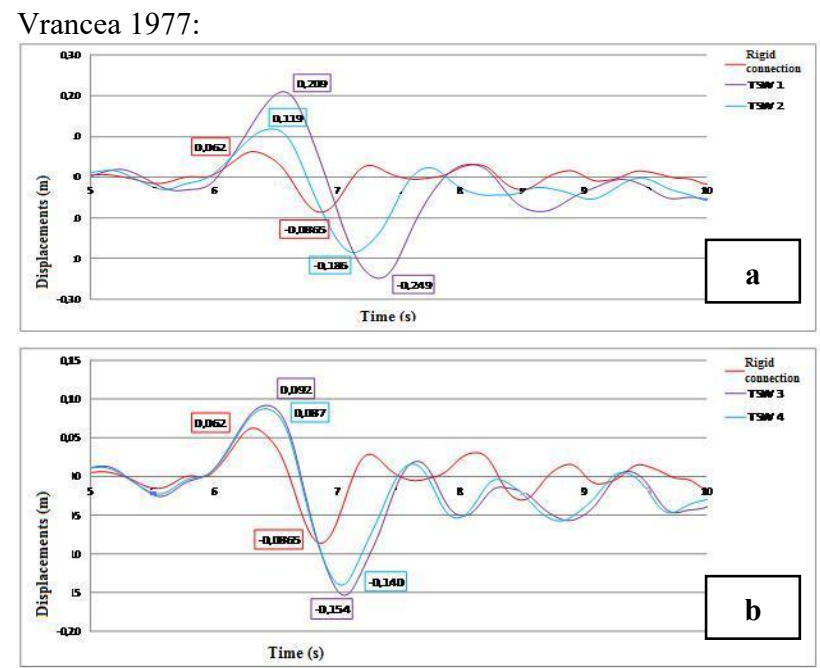

Vrancea 1977:
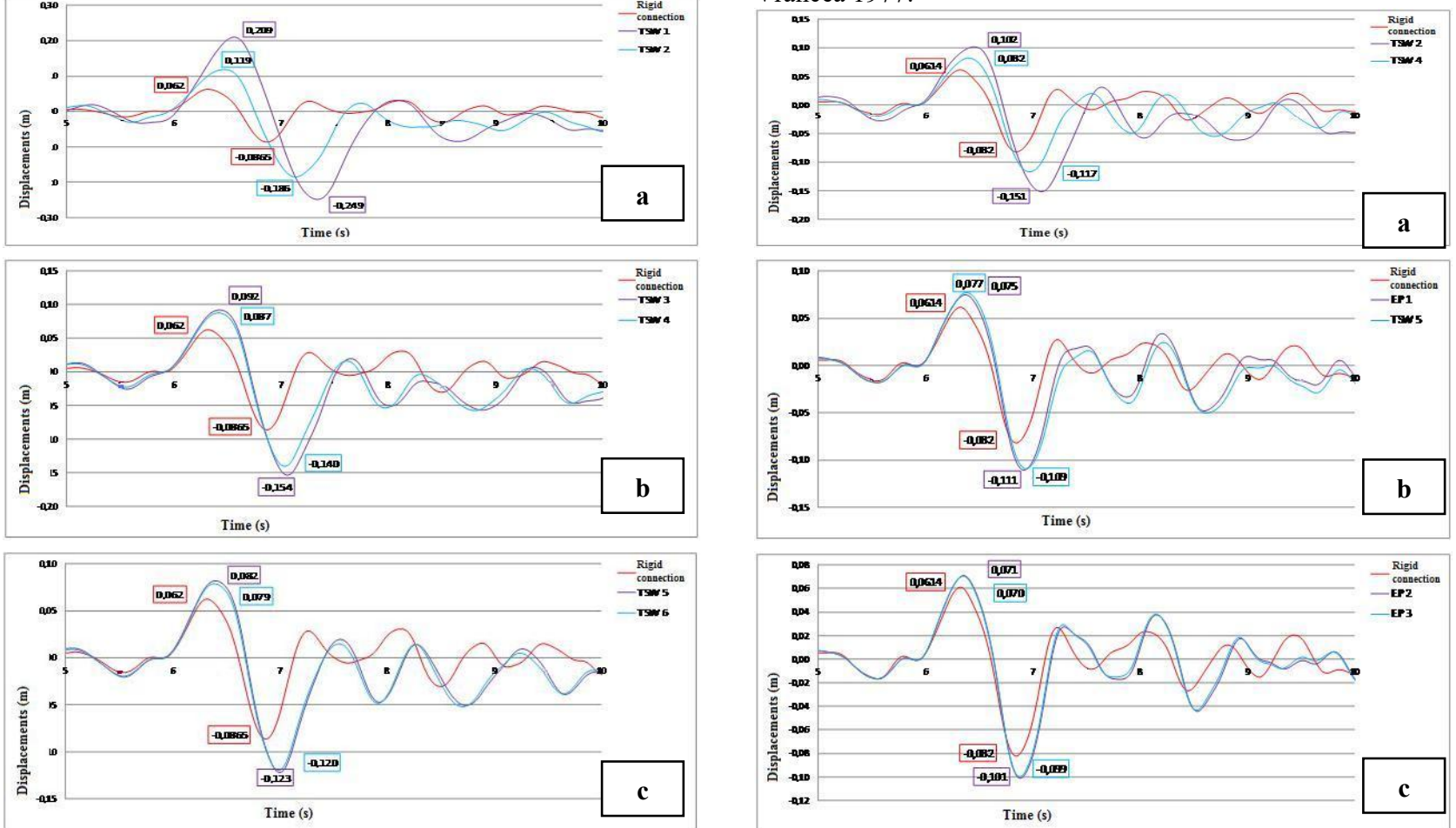

Figure 8. Top lateral displacements: a - Rigid connection, TSW 1, TSW 2; b - Rigid connection, TSW 3, TSW 4; c - Rigid connection, TSW 5, TSW 6

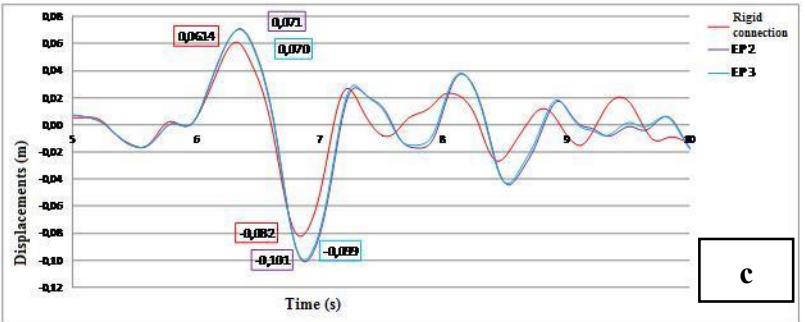

Figure 10. Top lateral displacements: a - Rigid connection, TSW 2, TSW 4; b - Rigid connection, TSW 1, TSW 5; c - Rigid connection, EP 2, EP 3 


\subsection{Relative floor lateral displacements}

\subsubsection{The case of four storey structure}
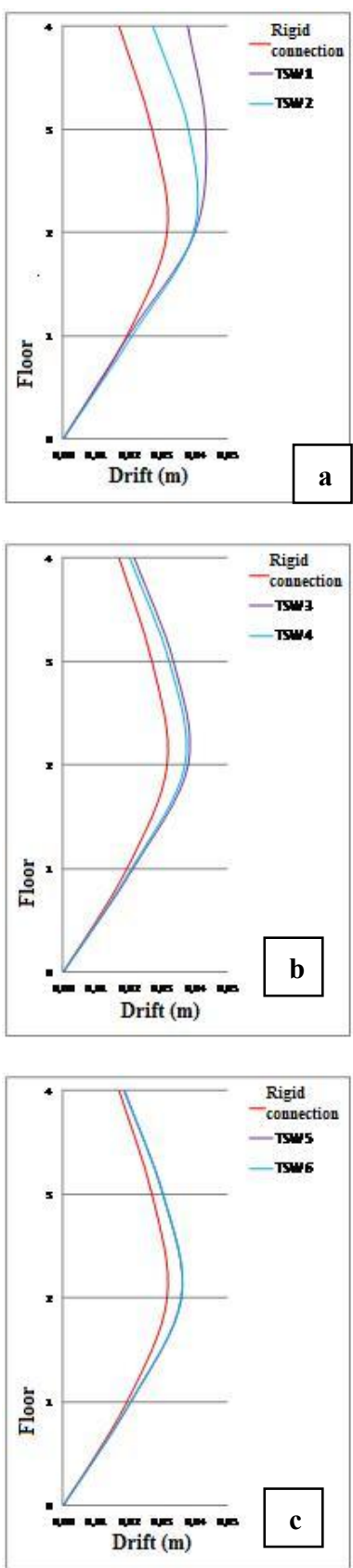

Figure 11. Relative floor lateral displacements: a- Rigid connection, TSW 1, TSW 2

b- Rigid connection, TSW 3, TSW 4 c- Rigid connection, TSW 5, TSW 6
Emeryville 1989:
Vrancea 1977:
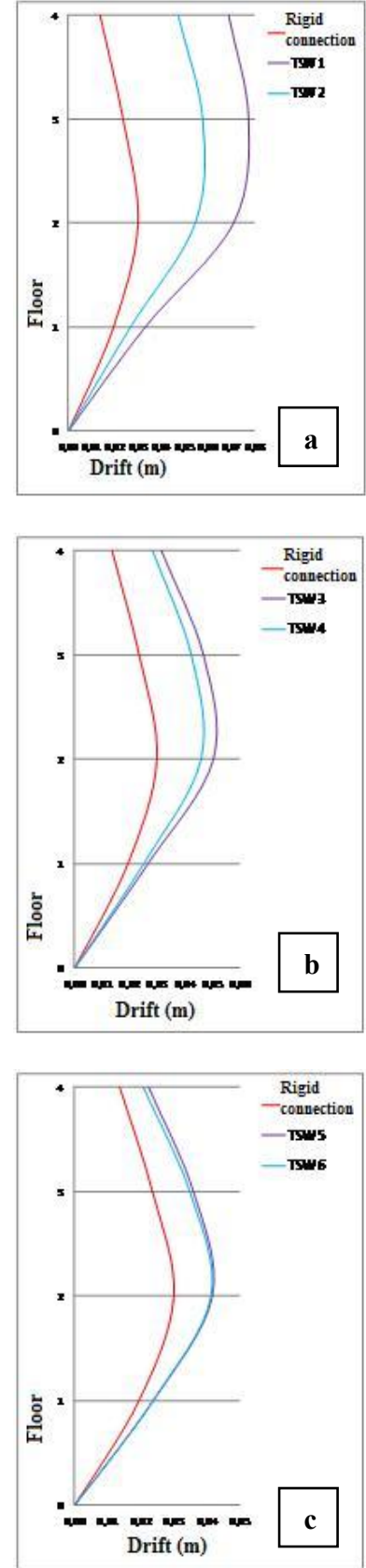

Figure 12. Relative floor lateral displacements: a- Rigid connection, TSW 1, TSW 2

b- Rigid connection, TSW 3, TSW 4

c- Rigid connection,
3.2.2. The case of six storey structure Emeryville 1989:

Vrancea 1977:
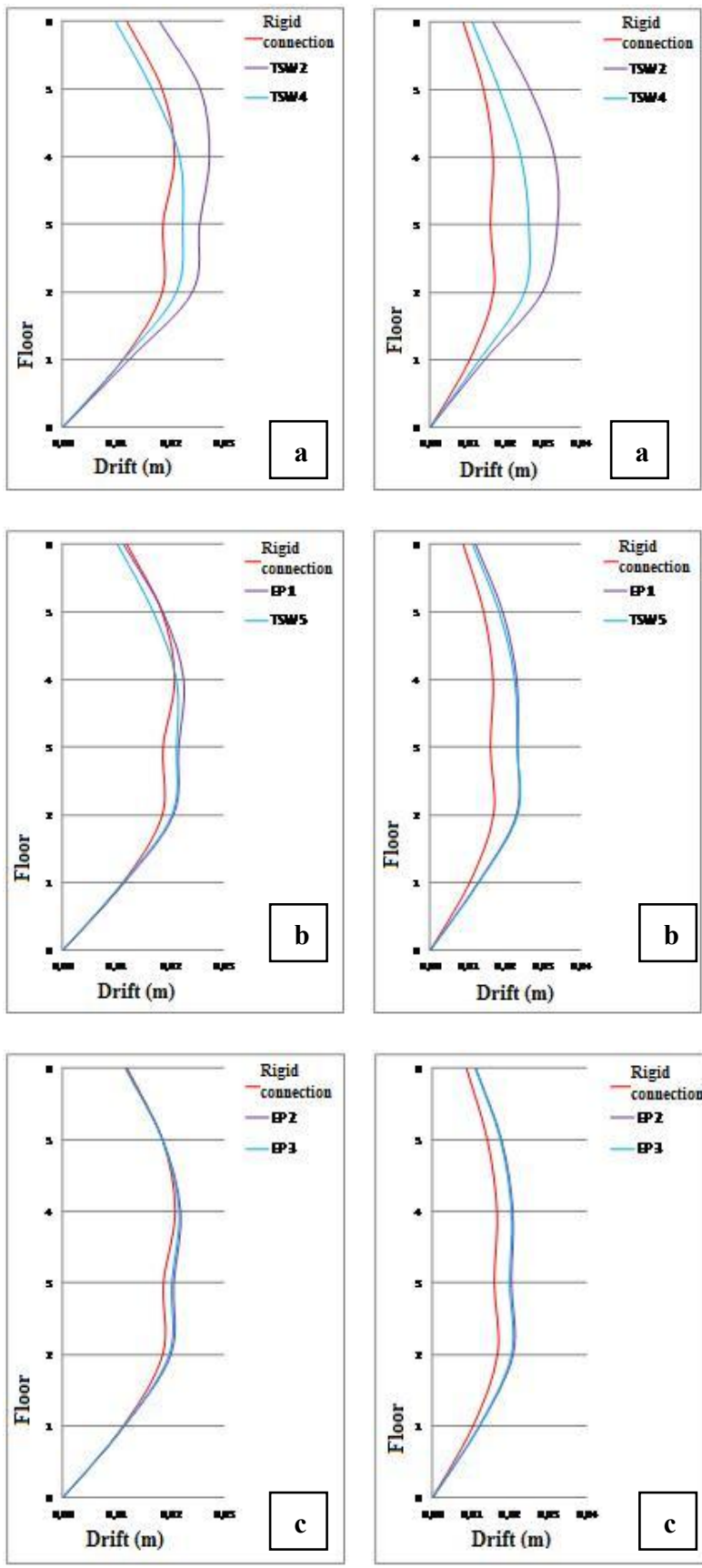

Figure 13. Relative floor lateral displacements:

a- Rigid connection, TSW 2, TSW 4

b- Rigid connection,

TSW 1, TSW 5

c- Rigid connection, EP 2, EP 3

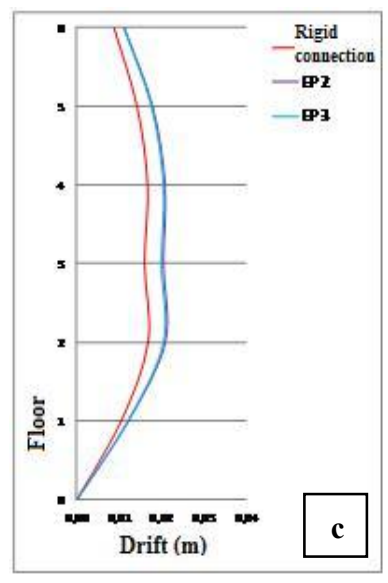

Figure 14. Relative floor lateral displacements: a- Rigid connection, TSW 2, TSW 4

b- Rigid connection,

TSW 1, TSW 5

c- Rigid connection, TEP 2, EP 3 


\subsection{Base shear seismic force}

\subsubsection{The case of four storey structure}

Emeryville 1989:
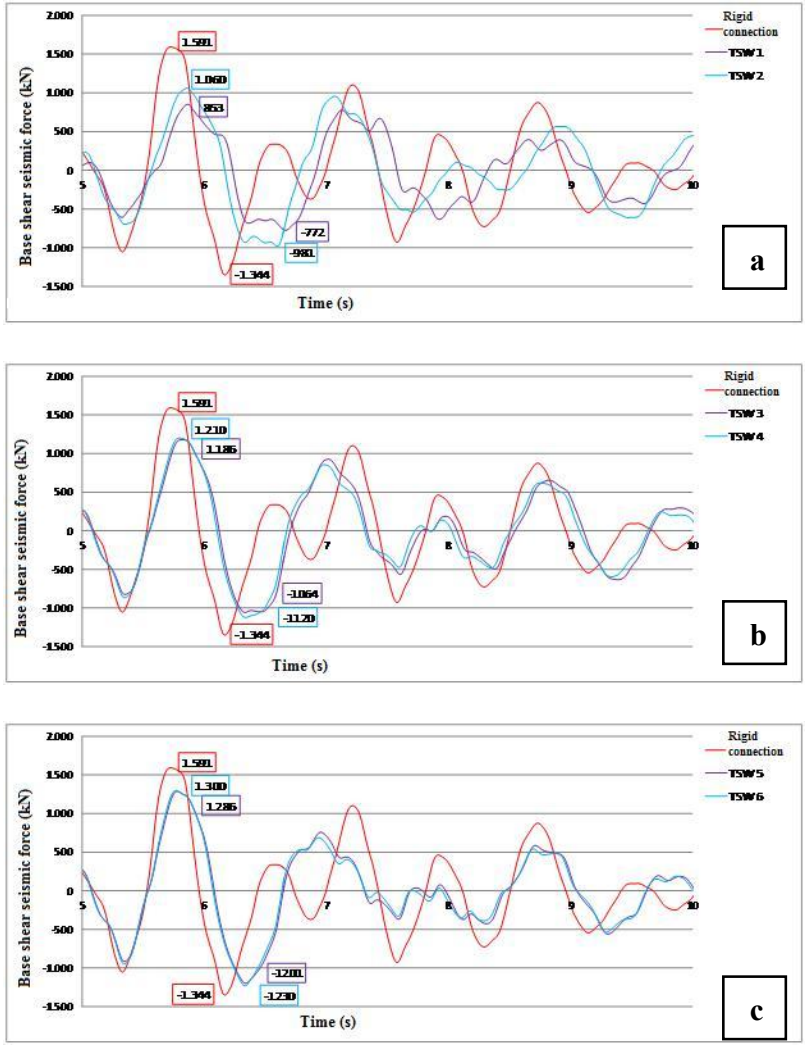

Figure 15. Base shear seismic force: a - Rigid connection, TSW 1, TSW 2; b - Rigid connection, TSW 3, TSW 4; c - Rigid connection, TSW 5, TSW 6

Vrancea 1977:
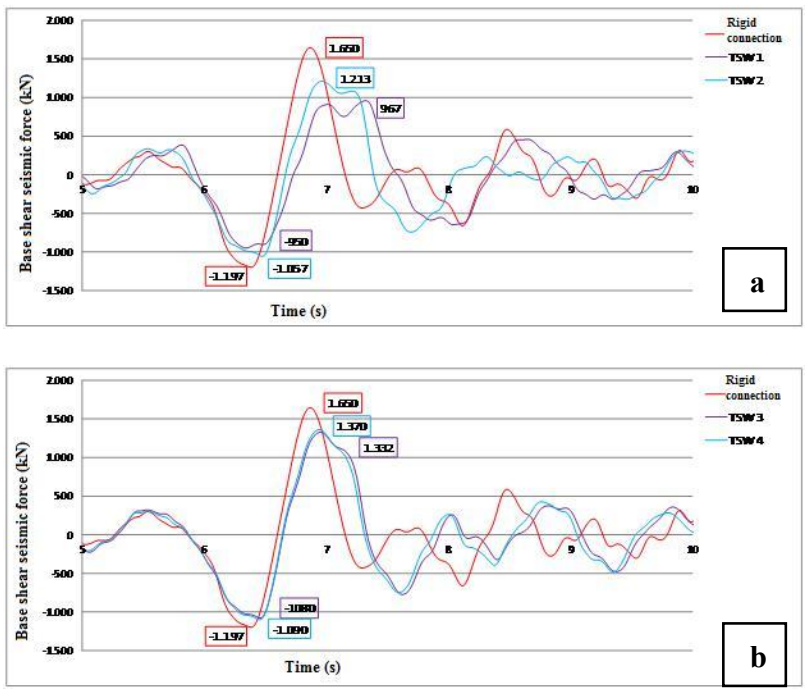

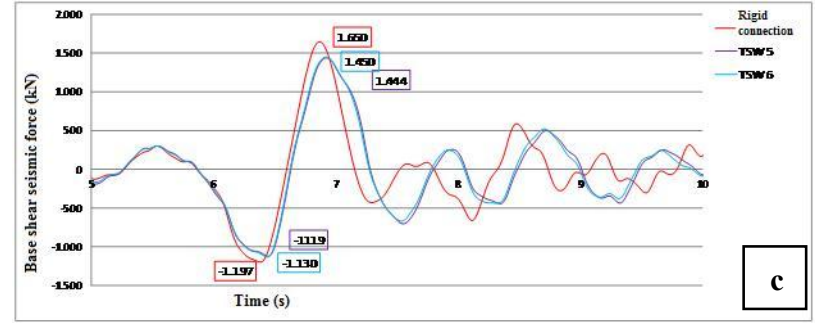

Figure 16. Base shear seismic force: a - Rigid connection, TSW

1, TSW 2; b - Rigid connection, TSW 3, TSW 4; c - Rigid connection, TSW 5, TSW 6

3.3.2. The case of six storey structure Emeryville 1989:
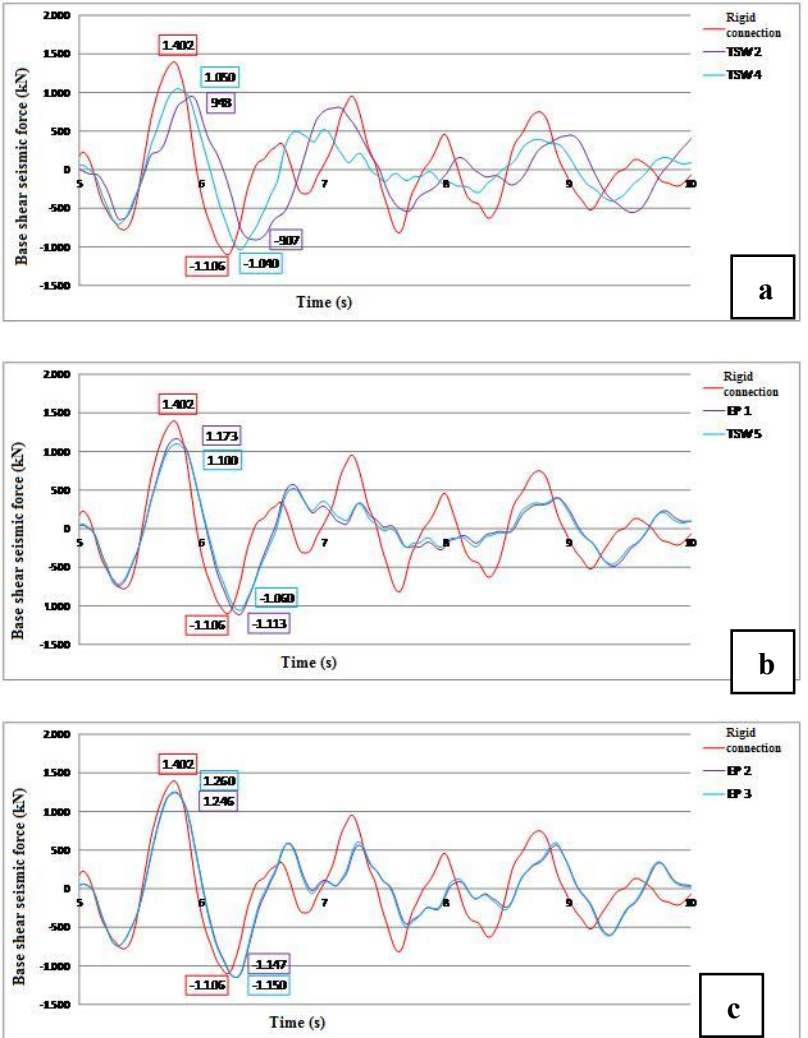

Figure 17. Base shear seismic force: a - Rigid connection, TSW 2, TSW 4; b - Rigid connection, EP 1, TSW 5; c - Rigid connection, EP 2, EP 3

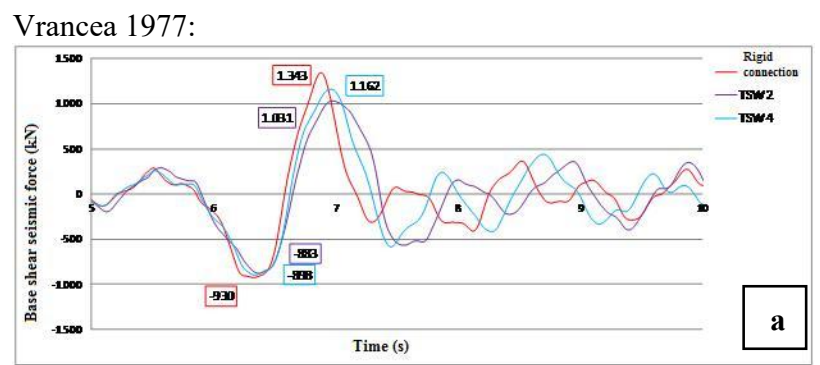



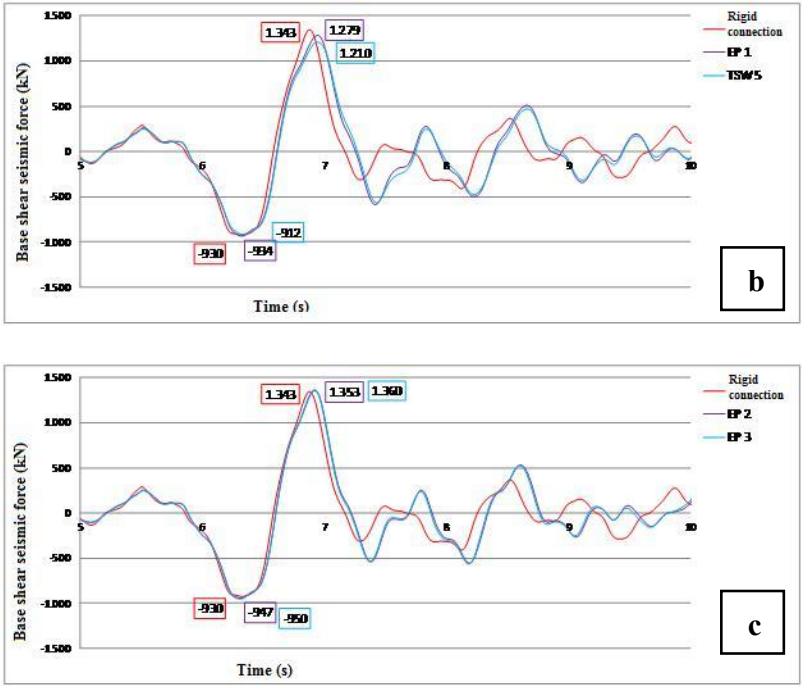

Figure 18. Base shear seismic force: a - Rigid connection, TSW 2, TSW 4; b - Rigid connection, EP 1, TSW 5; c - Rigid connection, EP 2, EP 3

\section{CONCLUDING REMARKS}

Seismic behaviour of multi - storey steel structures has been analyzed in several cases of semi-rigid connectivity and degree of semi -rigidity Presented numerical results are grouped such that emphasize static and kinematic states of seismic acted upon structures. In the design activity (structural conceiving and sectionally sizing) of structural engineer, the two mechanical states must be analyzed together since the semirigidity leads to contradictory results:

- A reduced seismic loading. Indeed, the increased flexibility of rigid structures leads to larger vibration periods, therefore to smaller base shear seismic forces. And, consequently, to reduced values of lateral statically equivalent seismic forces. This aspect may be regarded as advantageous from the point of view of sectional sizing.

- An amplified kinematic state expressed, mainly, through increased lateral displacements. It is the expected result of the same increased flexibility. This aspect is most important in structural design since imposed limits of seismically lateral displacements are the most pressing provision of modern structural design.

Obtained numerical results are graphically presented in a comparative manner that easily and directly allows a conclusion regarding the type of semi-rigid beam- column connections and degree of semi - rigidity.

The two seismic actions (Vrancea 1977, Emeryville 1989) have been selected for their closeness in what regards the maximum value of ground acceleration (around 1,95 m/ $/ \mathrm{sec}^{2} ; 1,96 \mathrm{~m} / \mathrm{sec}^{2}$ ) and predominant period $(1,16 \mathrm{sec}, 1,18 \mathrm{sec})$. Nevertheless, their different types (shock, succession of shocks gradually reduced) induce relevant semi-rigid behaviour in all studied cases. Unique shock type of Vrancea seismic action induces top lateral displacements much larger than the fading away of Emeryville type seismic action. The same relevant difference may be inferred from the static states induced by the two seismic actions: Vrancea type earthquakes are associated to larger base shear seismic forces than Emeryville type seismic forces. All computed and presented numerical results make up an expressive tableau of the seismically induced static and kinematic parameters.

\section{REFERENCES}

Abdalla, K. M. and Chen, W. F., 1995. Expanded Database of Semi-Rigid Steel Connections. Computer and Structures, AISC (American Institute of Steel Construction), Vol.56, No. 4, pp 553-564.

Al-Salloum, Y. A. and Almusallam, T. H., 1995. Optimality and Safety of Rigidly- and Flexibly-Jointed Steel Frames. Journal of Constructional Steel Research, Vol. 35, No. 2, pp 189-215.

Bjorhovde, R., Brozzetti, J., and Colson, A., 1990. A Classification System for Beam to column Connections. $J$. Struct. Engng., ASCE, 116 (11), 1990, pp. 3059-3076.

Chan, S.L., Huang, H.Y. and Fang, L.X., 2005. Advanced Analysis of Imperfect Portal Frames with Semi-Rigid Base Connections. Journal of Engineering Mechanics, Vol. 131, No. 6, pp 633-640.

Chan S.L. and Zhou, Z.H., 2000. Nonlinear Integrated Design and Analysis of Skeletal Structures. Engineering Structures, vol.22, no 3, pp 246-257.

Degertekin, S. O. and Hayalioglu, M. S., 2004. Design of Nonlinear Semi-Rigid Steel Frames with Semi-Rigid Column Bases. Electronic Journal of Structural Engineering, Vol. 4, pp $1-16$.

Del Savio, A. A., Nethercot D. A., Vellasco P. C. G. S., Andrade S. A. L., Martha L. F., 2009. A Generalised Component-Based Model for Semi-Rigid Beam-to-Column Connections Including the Axial versus Bending Moment Interaction. Journal of Constructional Steel Research, Vol. 65 (8-9), pp. 1876-1895.

Dubina, D. and Zaharia, R., 1996. The Influence of Node SemiRigidity of the Thin-Walled Steel Trusses Bolted Joints. ThinWalled Structures, Vol. 29, No. 1-4, pp. 273-287.

Goto, Y. and Miyashita, S., 1998. Classification System for Rigid and Semirigid Connections. Journal of Structural Engineering, ASCE, Vol. 124, No. 7, pp. 750-757.

Fang, C., Izzuddin, B. A., Elghazouli, A.Y., Nethercot, D. A., 2013. Modelling of Semi-Rigid Beam-to-Column Steel Joints Under Extreme Loading. Frontiers of Structural and Civil Engineering, volume 7, issue 3, pp 245-263.

Lima L. R. O., da Vellasco P. C. G., da Silva J. G. S., Borges L. A., 2005. Post-Limit Stiffness Prediction of Semi-Rigid 
DE GRUYTER

Joints Using Genetic Algorithms. Latin American Journal of Solids and Structures, Vol. 2 (3-4), pp. 305-320.

Kartal M.E., Başağa H.B. \& Bayraktar A., Muvafik M., 2010.

Effects of Semi-Rigid Connection on Structural Responses. Electronic Journal of Structural Engineering, (10), pp. 22-35.

Moldovan, C., 2016, Geometric Non- Linear Approach to Stiffness State of Semi -Rigid Structures. Journal of Applied Engineering Sciences, Vol. 6(19), ISSUE 1/2016, Art.No. 205, pp 63-70, Oradea, Romania.

Moldovan, C., 2005. Structuri metalice alcătuite din bare cu conexiuni elastice (Metallic structures with Elastically Connected Elements). Risoprint, Cluj-Napoca, Romania, pp.5481.

Eurocode, 2005. EN 1993-1-1 (2005) (English): Eurocode 3: Design of steel structures - Part 1-1: General rules and rules for buildings. Directive 98/34/EC, Directive 2004/18/EC, European Union Per Regulation 305/2011.

Moldovan, C., 1997. Modele mecanice și analitice în analiza structurilor metalice alcătuite din bare cu conexiuni elastice (Mechanical and Analytical Models in the Analysis of Metallic Structures with Elastically Connected Elements). PhD thesis, pp.41-57, pp.80-106, Technical University of Cluj-Napoca, Romania.

P100-1, 2013. P100-1, Seismic Design Code - Part I Provisions for building design (P100-1, Cod de proiectare seismică - Partea I - Prevederi de proiectare pentru clădiri). Technical University of Civil Engineering Bucharest, Romania, beneficiary - Ministry of Regional Development and Public Administration, Romania, May 2013.

Trahair, N.S., 2012. Trends in the Analysis and Design of Steel Framed Structures. Research Report R926, pp. 6-12, School of Civil Engineering, University of Sydney, NSW, Australia. 